\title{
Bacillus halochares sp. nov., a halophilic bacterium isolated from a solar saltern
}

\author{
Correspondence \\ A. I. Koukkou \\ akukku@cc.uoi.gr
}

\author{
A. Pappa, ${ }^{1}$ C. Sánchez-Porro, ${ }^{2}$ P. Lazoura, ${ }^{1}$ A. Kallimanis, ${ }^{1}$ A. Perisynakis, ${ }^{1}$ \\ A. Ventosa, ${ }^{2}$ C. Drainas ${ }^{1}$ and A. I. Koukkou ${ }^{1}$
${ }^{1}$ Sector of Organic Chemistry and Biochemistry, Department of Chemistry, University of loannina, 45110 loannina, Greece Sevilla, Spain \\ ${ }^{2}$ Department of Microbiology and Parasitology, Faculty of Pharmacy, University of Sevilla, 41012
}

\begin{abstract}
A novel halophilic bacterium, designated strain $\mathrm{MSS}^{\top}$, was isolated from the solar salterns of Mesolongi, Greece. The micro-organism, a motile, Gram-stain-positive, aerobic rod, proliferated at salinities of 1.0-4.0 M NaCl, with optimal growth at $2.5 \mathrm{M} \mathrm{NaCl}$. Endospores were not observed. Strain MSS4 $4^{\top}$ showed optimal growth at $37{ }^{\circ} \mathrm{C}$ and $\mathrm{pH}$ 8.0. The $\mathrm{G}+\mathrm{C}$ content of its DNA was 47.2 mol\%. The polar lipid pattern of strain $\mathrm{MSS}^{\top}{ }^{\top}$ consisted of diphosphatidylglycerol, phosphatidylglycerol, phosphatidic acid and phosphatidylethanolamine. It possessed anteiso-

$\mathrm{C}_{15: 0}, \mathrm{C}_{18: 0,}, \mathrm{C}_{16: 0}$ and anteiso- $\mathrm{C}_{17: 0}$ as the major fatty acids (altogether representing $84.7 \%$ of the total). The predominant isoprenoid quinone was MK-7. The cell-wall peptidoglycan contained meso-diaminopimelic acid. 16S rRNA gene sequence analysis showed that the new isolate has 96.1\% similarity to Bacillus qingdaonensis $\mathrm{CM}^{\top}{ }^{\top}$ and Bacillus aidingensis $17-5^{\top}, 95.5 \%$ to Bacillus salarius $\mathrm{BH} 169^{\top}$ and lower similarity to other Bacillus species. These results justify the assignment of strain $\mathrm{MSS}^{\top}$ to a novel species within the genus Bacillus, for which the name Bacillus halochares sp. nov. is proposed. The type strain is $\mathrm{MSS}^{\top}$ (=LMG $24571^{\top}=\mathrm{DSM}$ $\left.21373^{\top}\right)$.
\end{abstract}

Life exists over the whole range of salt concentrations encountered in natural habitats, from freshwater environments to hypersaline lakes (Oren, 2002a). Halophiles, saltloving organisms that inhabit hypersaline environments, include mainly prokaryotic and eukaryotic micro-organisms with the capacity to balance the osmotic pressure of the environment and resist the denaturing effects of salts (Oren, 2002a; Ventosa, 2006). The heterotrophic conditions at near-saturating salt concentrations $(3-5 \mathrm{M} \mathrm{NaCl})$ usually favour extremely halophilic haloarchaea (Oren, 2002b). The decreased microbial diversity in such environments has been studied with both culture-dependent and molecular methods (Burns et al., 2004). Indications that extremely halophilic micro-organisms other than haloarchaea may thrive in environments with salt concentration close to saturation have been provided recently (Antón et al., 2000, 2002; Eder et al., 2002; Maturrano et al., 2006a, b; Kharroub et al., 2006; Moreno et al., 2009). In an attempt to evaluate the diversity of halophilic microorganisms in Greek solar salterns, the Mesolongi thalassohaline salt works were chosen.

The Mesolongi salt works are located west of the town of Mesolongi (western central Greece). It is the biggest saltern

The GenBank/EMBL/DDBJ accession number for the 16S rRNA gene sequence of strain MSS4 ${ }^{\top}$ is $A M 982516$. in Greece, occupying an area of 1240 ha. Part of the saltern area has been used for salt production for several centuries, whereas a considerable expansion took place in the 1960s. The wetland type could be summarized as a semi-artificial saline ecosystem with an ample gradient of characteristics starting from a regular saline wetland (pre-basins) up to extreme hypersaline meadows (crystallizers). Salt is produced mainly during summer, from July to early October, by solar evaporation. Sample collection took place from soil as well as from low- and high-salinity concentrator pans (salinity 20 and $30 \%$, respectively) in August. Cultivation-dependent methods in combination with molecular techniques (16S rRNA gene sequence analysis) revealed that the higher salinity concentrator pan favoured growth of members of the haloarchaea (Haloterrigena, Haloferax and Halobacterium; unpublished results). Here, we report the isolation of a halophilic bacterium belonging to the genus Bacillus and its taxonomic characterization using a polyphasic approach.

Strain $\mathrm{MSS}^{\mathrm{T}}$ was isolated from a sample collected from soil of a crystallizer pond in August 2004. A soil sample of $20 \mathrm{~g}$ was inoculated in liquid medium SW $4 \mathrm{M} \mathrm{NaCl}$ and incubated for 7 days at $37{ }^{\circ} \mathrm{C}$. Medium SW $4 \mathrm{M} \mathrm{NaCl}$ contained (w/v) 23.4\% NaCl, 3.9\% $\mathrm{MgCl}_{2} \cdot 6 \mathrm{H}_{2} \mathrm{O}, 6.1 \%$ $\mathrm{MgSO}_{4} .7 \mathrm{H}_{2} \mathrm{O}, 0.1 \%$ anhydrous $\mathrm{CaCl}_{2}, 0.6 \% \mathrm{KCl}, 0.02 \%$ $\mathrm{NaHCO}_{3}$ and $0.5 \%$ yeast extract (Lab M); $\mathrm{MgCl}_{2}$ and 
$\mathrm{CaCl}_{2}$ were prepared separately and added to the solution after sterilization. The $\mathrm{pH}$ was adjusted to $7.2 \pm 0.2$ with $1 \mathrm{M} \mathrm{NaOH}$ prior to autoclaving. Dilutions of $100 \mu \mathrm{l}$ of the cultivation were plated on SW $4 \mathrm{M} \mathrm{NaCl}$ agar plates. Solid media were prepared by adding $2 \%(\mathrm{w} / \mathrm{v})$ agar (Lab M). Colonies were picked and subcultured repeatedly, so as to establish pure single-colony isolates. Cells of strain MSS4 ${ }^{\mathrm{T}}$ were grown in $100 \mathrm{ml}$ liquid medium SW at five salinities, $0.5,1.0,1.5,2.5$ and $4.0 \mathrm{M} \mathrm{NaCl}$, in $250 \mathrm{ml}$ Erlenmeyer flasks with shaking (150-200 r.p.m.) at $37^{\circ} \mathrm{C}$. Growth was monitored by measuring the $\mathrm{OD}_{600}$ throughout the growth curve until stationary phase was reached.

Cell morphology and motility were examined using a microscope equipped with phase-contrast optics. Biochemical tests were performed as outlined elsewhere (Smibert \& Krieg, 1994; Cappuccino \& Sherman, 1996; Sánchez-Porro et al., 2009) using cultures grown at $37^{\circ} \mathrm{C}$ in the appropriate medium. Bacillus qingdaonensis CIP $109642^{\mathrm{T}}$, Bacillus aidingensis DSM $18341^{\mathrm{T}}$ and Bacillus salarius DSM $16461^{\mathrm{T}}$ were used as reference strains and their features were compared with those of strain MSS4 ${ }^{\mathrm{T}}$ under the same laboratory conditions.

Template DNA was extracted from colonies of strain $\mathrm{MSS}^{\mathrm{T}}$ using the Nucleospin Tissue kit (Macherey-Nagel) according to the manufacturer's recommendations. The 16S rRNA gene was amplified from genomic DNA using the primers 16SF ( $5^{\prime}$-AGAGTTTGATCCTGGCTCAG-3') and 16SR (5'-AAGGAGGTGATCCAGCC-3') respectively corresponding to positions 9-27 and 1525-1542 of the 16S rRNA gene sequence of Escherichia coli (Stackebrandt \& Liesack, 1993). Hot-start PCR at $95{ }^{\circ} \mathrm{C}$ for $5 \mathrm{~min}$ was followed by 30 cycles of $94{ }^{\circ} \mathrm{C}$ for $1 \mathrm{~min}, 60{ }^{\circ} \mathrm{C}$ for $2 \mathrm{~min}$ and $72{ }^{\circ} \mathrm{C}$ for $3 \mathrm{~min}$, with a final chain-elongation step at $72{ }^{\circ} \mathrm{C}$ for $10 \mathrm{~min}$. The amplified DNA fragment of $1.5 \mathrm{~kb}$ was purified using the Nucleospin Extract II kit (MachereyNagel) following electrophoresis on a $0.7 \%$ agarose gel and sequenced using primers 16SF and 16SR by Macrogen (Seoul, Korea).

$16 \mathrm{~S}$ rRNA gene sequence analysis was performed with the ARB software package (Ludwig et al., 2004). The 16S rRNA gene sequence was aligned with published sequences of closely related bacteria and the alignment was confirmed and checked against both primary and secondary structures of the 16S rRNA molecule using the alignment tool of the ARB software package. Phylogenetic trees were constructed using three different methods, the maximum-likelihood (Felsenstein, 1981), maximum-parsimony (Fitch, 1971) and neighbour-joining (Saitou \& Nei, 1987) algorithms integrated in the ARB software for phylogenetic inference. $16 \mathrm{~S}$ rRNA gene sequences used for phylogenetic comparisons were obtained from GenBank; strain designations and accession numbers are shown in Fig. 1.

An almost-complete $16 \mathrm{~S}$ rRNA gene sequence (1426 bp) of strain $\mathrm{MSS}^{\mathrm{T}}$ was obtained and used for initial BLAST searches in GenBank and phylogenetic analysis. Identification of phylogenetic neighbours and calculation of pairwise $16 \mathrm{~S}$ rRNA gene sequence similarity were achieved using the EzTaxon server (http://www.eztaxon. org/; Chun et al., 2007). Phylogenetic analysis, based on the maximum-parsimony algorithm, revealed that strain $\mathrm{MSS}^{\mathrm{T}}$ formed a phyletic group with Bacillus qingdaonensis $\mathrm{CM}^{\mathrm{T}}$ and Bacillus aidingensis $17-5^{\mathrm{T}}$ (96.1\% similarity) as well as Bacillus salarius $\mathrm{BH} 169^{\mathrm{T}}$ (95.5\% similarity) (Fig. 1). The 16S rRNA gene sequence similarity between strain MSS4 $^{\mathrm{T}}$ and members of other Bacillus species was $\leqslant 91.5 \%$. Neighbour-joining and maximum-likelihood methods resulted in highly similar tree topologies, and only the maximum-parsimony results are shown. Based on the sequence divergence, it was evident that strain MSS4 ${ }^{\mathrm{T}}$ constituted a different taxon separated from other Bacillus species.

Cells of isolate MSS4 ${ }^{\mathrm{T}}$ were Gram-stain-positive, aerobic, motile rods. Endospores were not observed. Growth was observed at 1.0-4.0 M NaCl, with an optimum at $2.5 \mathrm{M}$. No growth was observed on SW agar without $\mathrm{NaCl}$. The temperature range was $26-45{ }^{\circ} \mathrm{C}$, with optimum growth at $37{ }^{\circ} \mathrm{C}$. The $\mathrm{pH}$ range was $6.0-9.0$, with optimum growth at $\mathrm{pH}$ 8.0. Standard bacteriological and biochemical methods described above were applied for phenotypic characterization. All media used were supplemented with $2.5 \mathrm{M} \mathrm{NaCl}$. Catalase and oxidase tests were positive, whereas tests for urease, amylase and gelatinase activities and nitrate reduction as well as $\mathrm{H}_{2} \mathrm{~S}$ production were negative. Other

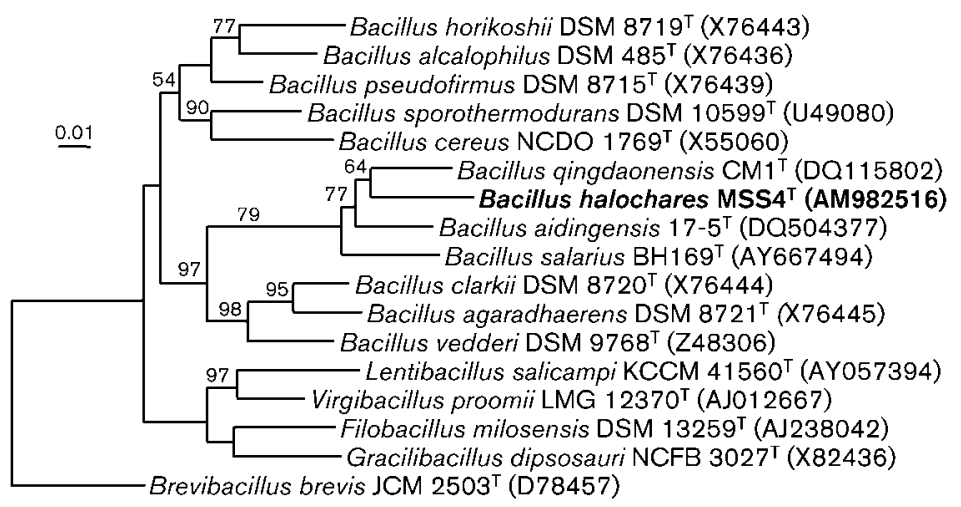

http://ijs.sgmjournals.org
Fig. 1. Maximum-parsimony phylogenetic tree, based on 16S rRNA gene sequences, showing the relationships of strain $M S S 4^{\top}$ and the type strains of related taxa. GenBank accession numbers are shown in parentheses. Brevibacillus brevis JCM $2503^{\top}$ was used as an outgroup. Bar, 0.01 substitutions per nucleotide position. 
phenotypic features are included in the species description and in Table 1.

Phospholipid and fatty acid (FAME) analysis were performed as described by Kallimanis et al. (2007) and references therein. Cells were cultured on SW medium at $\mathrm{pH} 7.2,37{ }^{\circ} \mathrm{C}$ for $24 \mathrm{~h}\left(\mathrm{OD}_{600} 0.7\right)$. Analysis of quinones and cell-wall peptidoglycan was carried out by the Identification Service and $\operatorname{Dr}$ B. J. Tindall, DSMZ, Braunschweig, Germany. The major fatty acids were anteiso- $\mathrm{C}_{15: 0}(35.5 \%), \mathrm{C}_{18: 0}$ (21.9\%), $\mathrm{C}_{16: 0} \quad(16.9 \%)$ and anteiso- $\mathrm{C}_{17: 0}(10.4 \%)$. The major phospholipids were diphosphatidylglycerol, phosphatidylglycerol, phosphatidic acid and phosphatidylethanolamine $(35.6 \pm 4.1,35.0 \pm 3.9$, $4.9 \pm 1.2$ and $4.8 \pm 0.9 \%$ respectively). The major isoprenoid quinone of strain $\mathrm{MSS}^{\mathrm{T}}$ was menaquinone MK-7 and the cell-wall type was based on meso-diaminopimelic acid. The respiratory lipoquinone and peptidoglycan type of the cell wall of strain MSS4 ${ }^{\mathrm{T}}$ were typical of those found in members of the genus Bacillus (Priest et al., 1988; Heyrman et al., 2004, 2005; Wieser et al., 2005; Lim et al., 2006).

The $\mathrm{G}+\mathrm{C}$ content of the genomic DNA was determined from the midpoint value of the thermal denaturation profile (Marmur \& Doty, 1962) using the equation of Owen \& Hill (1979), as described previously in detail (Ventosa et al., 1999). The G+C content of the DNA of strain $\mathrm{MSS}^{\mathrm{T}}{ }^{\mathrm{T}}$ was $47.2 \mathrm{~mol} \%$. This value is close to those reported for B. qingdaonensis (Wang et al., 2007) and B. aidingensis (Xue et al., 2008), but quite different from that of B. salarius (Lim et al., 2006) (Table 1).

Overall, our data show that strain $\mathrm{MSS}^{\mathrm{T}}$ is placed phylogenetically within the radiation of the genus Bacillus, but the 16S rRNA gene sequence similarity with

Table 1. Characteristics that distinguish strain $M S S 4^{\top}$ from type strains of related species of the genus Bacillus

Strains: 1 , MSS4 $4^{\mathrm{T}} ; 2$, B. qingdaonensis CIP $109642^{\mathrm{T}}$ (Wang et al., 2007); 3, B. aidingensis DSM $18341^{\mathrm{T}}$ (Xue $^{\text {X }}$ et al., 2008); 4, B. salarius DSM $16461^{\mathrm{T}}$ (Lim et al., 2006). Data for reference type strains were taken from the publications listed unless indicated.

\begin{tabular}{|c|c|c|c|c|}
\hline Characteristic & 1 & 2 & 3 & 4 \\
\hline Cell width $(\mu \mathrm{m})$ & $0.5-0.7$ & $0.3-0.4$ & $0.2-0.4$ & $0.5-0.7$ \\
\hline Cell length $(\mu \mathrm{m})$ & $1.7-3.5$ & $1.8-3.2$ & $1.3-2.5$ & $1.3-1.9$ \\
\hline Pigmentation ${ }^{\star}$ & $\mathrm{C}$ & C & $\mathrm{C}-\mathrm{WH}$ & $\mathrm{C}-\mathrm{WH}$ to $\mathrm{Y}$ \\
\hline Endospore formation & - & - & + & + \\
\hline Spore shape $\dagger$ & $\mathrm{NA}$ & NA & E & ST \\
\hline Oxidase & + & - & - & + \\
\hline Motility & + & - & + & - \\
\hline \multicolumn{5}{|c|}{$\mathrm{NaCl}$ concentration for growth $(\%, \mathrm{w} / \mathrm{v})$} \\
\hline Range & $6-23$ & $2.5-20$ & $8-33$ & $3-20$ \\
\hline Optimum & 15 & 12 & 12 & $10-12$ \\
\hline \multicolumn{5}{|l|}{ Temperature for growth $\left({ }^{\circ} \mathrm{C}\right)$} \\
\hline Range & $26-45$ & $25-45$ & $22-44$ & $15-40$ \\
\hline Optimum & 37 & 37 & 37 & 30 \\
\hline \multicolumn{5}{|l|}{$\mathrm{pH}$ for growth } \\
\hline Range & $6.0-9.0$ & $6.5-10.5$ & $6.0-9.5$ & $6.8-9.5$ \\
\hline Optimum & 8.0 & 9 & 7.2 & 8.0 \\
\hline \multicolumn{5}{|l|}{ Acid production from: } \\
\hline D-Arabinose & - & $-\ddagger$ & $+\ddagger$ & $+\S$ \\
\hline Lactose & - & + & - & $+\S$ \\
\hline Maltose & - & $-\ddagger$ & $+\S$ & + \\
\hline Sucrose & + & + & - & $-\ddagger$ \\
\hline D-Xylose & + & + & - & + \\
\hline Nitrate reduction & - & $+\S$ & + & $-\S$ \\
\hline Hydrolysis of gelatin & - & - & $+\S$ & $-\ddagger$ \\
\hline Urease activity & - & $+\S$ & - & - \\
\hline DNA G $+\mathrm{C}$ content $(\mathrm{mol} \%)$ & 47.2 & 48 & 48.1 & 43 \\
\hline
\end{tabular}

${ }^{\star} \mathrm{C}$, Cream; wH, white; $\mathrm{Y}$, yellow.

$\dagger$ E, Ellipsoidal; ST, spherical, terminal; NA, not applicable.

$\ddagger$ Data from this study.

$\S$ Data from this study; a different reaction was reported in the original description. 
the type strains of the closest Bacillus species suggests that it could represent a different species; it also shows several phenotypic differences from the most closely related species (Table 1), justifying the proposal of a novel species, for which we suggest the name Bacillus halochares sp. nov.

\section{Description of Bacillus halochares sp. nov.}

Bacillus halochares [ha.lo.cha'res. Gr. masc. n. hals, halos salt; N.L. part. adj. chares from Gr. v. chairo to rejoice at, to delight in; N.L. part. adj. halochares finding pleasure in salt (salty environments)].

Cells are Gram-stain-positive, motile rods, $0.5-0.7 \times 1.7-$ $3.5 \mu \mathrm{m}$. Endospores are not observed. Colonies are circular, entire, cream and approximately $1 \mathrm{~mm}$ in diameter after cultivation on SW medium at $37^{\circ} \mathrm{C}$ for 24 h. Strictly aerobic. Moderately halophilic. Growth occurs at $\mathrm{NaCl}$ concentrations of 1.0-4.0 M (optimum $2.5 \mathrm{M} \mathrm{NaCl}$ ). No growth occurs in the absence of $\mathrm{NaCl}$. Temperature range for growth is $26-45{ }^{\circ} \mathrm{C}$ (optimum $37^{\circ} \mathrm{C}$ ). Grows at $\mathrm{pH}$ 6.0-9.0 (optimum pH 8.0). Catalaseand oxidase-positive, urease-negative. Aesculin is hydrolysed but not amylase, gelatin, casein, Tween 80 or DNA. Nitrate is not reduced. $\mathrm{H}_{2} \mathrm{~S}$ is not produced. Acid is produced from D-fructose, D-galactose, D-glucose, glycerol, D-mannitol, D-mannose, sucrose, trehalose and D-xylose but not from $\mathrm{D}$-arabinose, lactose, maltose, raffinose or sorbitol. The following compounds are utilized as sole carbon and energy sources: starch, cellobiose, lactose, maltose, ribose, sucrose, glycerol, D-mannitol and acetate. The following compounds are not utilized as sole carbon and energy sources: D-arabinose, D-fructose, D-fucose, Dgalactose, D-glucose, D-mannose, melibiose, raffinose, trehalose, D-xylose, butanol, dulcitol, ethanol, myo-inositol, propanol, D-sorbitol, xylitol, methanol, benzoate, citrate, formate, fumarate, propionate, succinate and valerate. The following compounds are not used as sole carbon, nitrogen and energy sources: L-arginine, aspartic acid, L-cysteine, L-phenylalanine, glutamic acid, L-methionine, L-ornithine, L-serine and tryptophan. L-Alanine is used as a sole source of carbon, nitrogen and energy. The major menaquinone is MK-7. Major fatty acids are anteiso$\mathrm{C}_{15: 0}, \mathrm{C}_{18: 0}, \mathrm{C}_{16: 0}$ and anteiso- $\mathrm{C}_{17: 0}$. The major phospholipids are diphosphatidylglycerol, phosphatidylglycerol, phosphatidic acid and phosphatidylethanolamine. The diagnostic diamino acid in the cell-wall peptidoglycan is meso-diaminopimelic acid. The DNA G $+\mathrm{C}$ content of the type strain is $47.2 \mathrm{~mol} \%\left(T_{\mathrm{m}}\right)$.

The type strain, MSS4 ${ }^{\mathrm{T}}\left(=\mathrm{LMG} 24571^{\mathrm{T}}=\mathrm{DSM} 21373^{\mathrm{T}}\right)$, was isolated from soil of a crystallizer pond of the solar salterns at Mesolongi (Greece).

\section{Acknowledgements}

We wish to thank Dr Ioannis Leonardos from the Department of Biological Application and Technologies, University of Ioannina, for sampling in the Mesolongi salterns. We also wish to thank Dr Anastasia Badeca from the Food Quality Certification Unit for performing the GC-MS measurements and Professor Ioannis Perysinakis from the Department of Philology of the University of Ioannina for his valuable contribution to the species name. This study was supported by grants from the Spanish Ministerio de Ciencia y Tecnologia (BIO2009-10138) and the Junta de Andalucía (P06-CVI01829).

\section{References}

Antón, J., Rosselló-Mora, R., Rodríguez-Valera, F. \& Amann, R. (2000). Extremely halophilic bacteria in crystallizer ponds from solar salterns. Appl Environ Microbiol 66, 3052-3057.

Antón, J., Oren, A., Benlloch, S., Rodríguez-Valera, F., Amann, R. \& Rosselló-Mora, R. (2002). Salinibacter ruber gen. nov., sp. nov., a novel, extremely halophilic member of the Bacteria from saltern crystallizer ponds. Int J Syst Evol Microbiol 52, 485-491.

Burns, D. G., Camakaris, H. M., Jansenn, P. H. \& Dyall-Smith, M. L. (2004). Combined use of cultivation-dependent and cultivationindependent methods indicates that members of most haloarchaeal groups in an Australian crystallizer pond are cultivable. Appl Environ Microbiol 70, 5258-5265.

Cappuccino, J. G. \& Sherman, N. (1996). Microbiology: a Laboratory Manual. Menlo Park, CA: Benjamin/Cummings.

Chun, J., Lee, J.-H., Jung, Y., Kim, M., Kim, S., Kim, B. K. \& Lim, Y.-W. (2007). EzTaxon: a web-based tool for the identification of prokaryotes based on $16 \mathrm{~S}$ ribosomal RNA gene sequences. Int J Syst Evol Microbiol 57, 2259-2261.

Eder, W., Schmidt, M., Koch, M., Garbe-Schönberg, D. \& Huber, R. (2002). Prokaryotic phylogenetic diversity and corresponding geochemical data of the brine-seawater interface of the Shaban Deep, Red Sea. Environ Microbiol 4, 758-763.

Felsenstein, J. (1981). Evolutionary trees from DNA sequences: a maximum likelihood approach. J Mol Evol 17, 368-376.

Fitch, W. M. (1971). Toward defining the course of evolution: minimum change for a specific tree topology. Syst Zool 20, 406416.

Heyrman, J., Vanparys, B., Logan, N. A., Balcaen, A., Rodriguez-Diaz, M., Felske, A. \& De Vos, P. (2004). Bacillus novalis sp. nov., Bacillus vireti sp. nov., Bacillus soli sp. nov., Bacillus bataviensis sp. nov. and Bacillus drentensis sp. nov., from the Drentse A grasslands. Int J Syst Evol Microbiol 54, 47-57.

Heyrman, J., Rodriguez-Diaz, M., Devos, J., Felske, A., Logan, N. A. \& De Vos, P. (2005). Bacillus arenosi sp. nov., Bacillus arvi sp. nov. and Bacillus humi sp. nov., isolated from soil. Int J Syst Evol Microbiol 55, 111-117.

Kallimanis, A., Frillingos, S., Drainas, C. \& Koukkou, A. I. (2007). Taxonomic identification, phenanthrene uptake activity, and membrane lipid alterations of the PAH degrading Arthrobacter sp. strain Sphe3. Appl Microbiol Biotechnol 76, 709-717.

Kharroub, K., Aguilera, M., Quesada, T., Morillo, J. A., RamosCormenzana, A., Boulharouf, A. \& Monteoliva-Sánchez, M. (2006). Salicola salis sp. nov., an extremely halophilic bacterium isolated from Ezzemoul sabkha in Algeria. Int J Syst Evol Microbiol 56, 2647-2652.

Lim, J.-M., Jeon, C. O., Lee, S.-M., Xu, L. H., Jiang, C.-L. \& Kim, C.-J. (2006). Bacillus salarius sp. nov., a halophilic, spore-forming bacterium isolated from a salt lake in China. Int J Syst Evol Microbiol 56, 373-377.

Ludwig, W., Strunk, O., Westram, R., Richter, L., Meier, H., Yadhukumar, Buchner, A., Lai, T., Steppi, S. \& other authors (2004). ARB: a software environment for sequence data. Nucleic Acids Res 32, 1363-1371. 
Marmur, J. \& Doty, P. (1962). Determination of the base composition of deoxyribonucleic acid from its thermal denaturation temperature. J Mol Biol 5, 109-118.

Maturrano, L., Santos, F., Rosselló-Mora, R. \& Antón, J. (2006a). Microbial diversity in Maras salterns, a hypersaline environment in the Peruvian Andes. Appl Environ Microbiol 72, 3887-3895.

Maturrano, L., Valens-Vadell, M., Rosselló-Mora, R. \& Antón, J. (2006b). Salicola marensis gen. nov., sp. nov., an extremely halophilic bacterium isolated from the Maras salterns in Peru. Int J Syst Evol Microbiol 56, 1685-1691.

Moreno, M. L., García, M. T., Ventosa, A. \& Mellado, E. (2009). Characterization of Salicola sp. IC10, a lipase- and proteaseproducing extreme halophile. FEMS Microbiol Ecol 68, 59-71.

Oren, A. (2002a). Diversity of halophilic microorganisms: environments, phylogeny, physiology, and applications. J Ind Microbiol Biotechnol 28, 56-63.

Oren, A. (2002b). Molecular ecology of extremely halophilic archaea and bacteria. FEMS Microbiol Ecol 39, 1-7.

Owen, R. J. \& Hill, L. R. (1979). The estimation of base compositions, base pairing and genome sizes of bacterial deoxyribonucleic acids. In Identification Methods for Microbiologists (Society for Applied Bacteriology Technical Series no. 14), 2nd edn, pp. 277-296. Edited by F. A. Skinner \& D. W. Lovelock. London: Academic Press.

Priest, F. G., Goodfellow, M. \& Todd, C. (1988). A numerical classification of the genus Bacillus. J Gen Microbiol 134, 1847-1882.

Saitou, N. \& Nei, M. (1987). The neighbor-joining method: a new method for reconstructing phylogenetic trees. Mol Biol Evol 4, 406425.

Sánchez-Porro, C., de la Haba, R. R., Soto-Ramírez, N., Márquez, M. C., Montalvo-Rodríguez, R. \& Ventosa, A. (2009). Description of Kushneria aurantia gen. nov., sp. nov., a novel member of the family
Halomonadaceae, and a proposal for reclassification of Halomonas marisflavi as Kushneria marisflavi comb. nov., of Halomonas indalinina as Kushneria indalinina comb. nov. and of Halomonas avicenniae as Kushneria avicenniae comb. nov. Int J Syst Evol Microbiol 59, 397-405.

Smibert, R. M. \& Krieg, N. R. (1994). Phenotypic characterization. In Methods for General and Molecular Bacteriology, pp. 607-654. Edited by P. Gerhardt, R. G. E. Murray, W. A. Wood \& N. R. Krieg. Washington, DC: American Society for Microbiology.

Stackebrandt, E. \& Liesack, W. (1993). Nucleic acids and classification. In Handbook of New Bacterial Systematics, pp. 152-189. Edited by M. Goodfellow \& A. G. O’Donnell. London: Academic Press.

Ventosa, A. (2006). Unusual micro-organisms from unusual habitats: hypersaline environments. In Prokaryotic Diversity: Mechanisms and Significance (Society for General Microbiology Symposium no. 66), pp. 223-253. Edited by N. A. Logan, H. M. Lappin-Scott \& P. C. F. Oyston. Cambridge: Cambridge University Press.

Ventosa, A., Gutierrez, M. C., Kamekura, M. \& Dyall-Smith, M. L. (1999). Proposal to transfer Halococcus turkmenicus, Halobacterium trapanicum JCM 9743 and strain GSL-11 to Haloterrigena turkmenica gen. nov., comb. nov. Int J Syst Bacteriol 49, 131-136.

Wang, Q. F., Li, W., Liu, Y. L., Cao, H. H., Li, Z. \& Guo, G. Q. (2007). Bacillus qingdaonensis sp. nov., a moderately haloalkaliphilic bacterium isolated from a crude sea-salt sample collected near Qingdao in eastern China. Int J Syst Evol Microbiol 57, 1143-1147.

Wieser, M., Worliczek, H., Kämpfer, P. \& Busse, H.-J. (2005). Bacillus herbersteinensis sp. nov. Int J Syst Evol Microbiol 55, 2119-2123.

Xue, Y., Ventosa, A., Wang, X., Ren, P., Zhou, P. \& Ma, Y. (2008). Bacillus aidingensis sp. nov., a moderately halophilic bacterium isolated from Ai-Ding salt lake in China. Int J Syst Evol Microbiol 58, $2828-2832$. 